\title{
Stability of prothrombin and factor VII in freeze-dried plasma
}

\author{
M. BROZOVIĆ, L. J. GURD, I. ROBERTSON, AND D. R. BANGHAM \\ From the Division of Biological Standards and the Statistical Services Section, National Institute for \\ Medical Research, Mill Hill, London
}

SYNOPSIS The stability of prothrombin and factor VII was studied using accelerated degradation $\tilde{\perp}$ tests in three preparations of freeze-dried pooled normal plasmas. In a previous report (Brozovic, Gurd, Robertson, and Bangham, 1971) factor X was shown to be relatively unstable in these pre- $\&$ parations of freeze-dried plasma: it was calculated that up to $8 \%$ of the original factor $\mathrm{X}$ activityo would be lost after 10 years at $-20^{\circ} \mathrm{C}$, up to $54 \%$ at $4{ }^{\circ} \mathrm{C}$, and up to $90 \%$ at room temperature.

The losses of factor VII activity were estimated to be negligible at $-20^{\circ} \mathrm{C}$, between 2 and $18 \% \bar{z}$ at $4^{\circ} \mathrm{C}$, and between 20 and $70 \%$ of the original activity at $20^{\circ} \mathrm{C}$, after 10 years of storage. Prothrombin was found to be less stable than factor VII: the expected loss in 10 years at $-20^{\circ} \mathrm{C}$ may be up

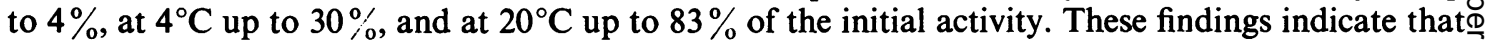
in freeze-dried plasma prothrombin as well as factor X may be insufficiently scable for plasma to $\overrightarrow{0}$ serve as long-term reference material for the standardization of the one-stage prothrombin time. $\rightarrow$ Moreover, the loss of prothrombin and factor $\mathrm{X}$ in freeze-dried plasma stored at $4^{\circ} \mathrm{C}$ may be sohigh that when it is required to preserve these factors it may be necessary to store freeze-dried plasma at lower temperatures.

During the past several years attempts have been made to devise a generally acceptable method of standardization of one-stage prothrombin times. There is now general agreement that the thromboplastin sensitivity ratio of Biggs and Denson (1967) obtained with characterized thromboplastin preparations can be employed to compare prothrombin time results obtained in different laboratories using different thromboplastin preparations. Another approach has been proposed by Miale and LaFond (1967). Freeze-dried reference plasmas of determined clotting factor content are used to test the performance of different thromboplastins. It has been suggested that the two approaches might be combined, and characterized thromboplastin used in conjunction with freeze-dried reference plasma preparations to test different thromboplastins in a simplified system, as outlined by Biggs and Bangham (1971). The long-term stability of both reference thromboplastin and reference plasmas is of the utmost importance if such a system were to be relied upon over a period of years.

Preparations of two thromboplastins, one human and one bovine, were characterized in a collaborative

Received for publication 4 March 1971. study (Bangham, Biggs, Brozović, and Denson, $\stackrel{2}{\overrightarrow{2}}$ 1970) and shown to be very stable in accelerated을 degradation tests over a period of two years. The $\bar{\partial}$ stability of three additional thromboplastins (two rabbit and one human preparations) is currently being studied. Loeliger and colleagues (Loeliger? Menwisse-Braun, Buitendijk, Veltkamp, and Hem- $\frac{0}{3}$ ker, 1970) have shown that pooled normal plasma and pooled plasma from patients stabilized on $\frac{\mathrm{C}}{3}$ long-term anticoagulant treatment, stored in small aliquots at $-70^{\circ} \mathrm{C}$, gives reproducible results over윽 a period of some years. Miale and LaFond (1969) tested their freeze-dried reference plasmas after 10 months' storage (temperature not specified), and $N$ showed that little change in prothrombin times occurred.

We have recently studied the stability of factor $X \mathrm{~N}$ in some preparations of freeze-dried plasma and found that factor $\mathrm{X}$ activity decreased on storage. When degradation constants were calculated and the $\frac{\varnothing}{\varnothing}$ loss of potency estimated, it became apparent that $\stackrel{+}{+}$ up to $8 \%$ of the initial factor $X$ activity could be $\frac{T}{T}$ lost in 10 years if the ampoules were stored at $-20^{\circ} \mathrm{C}$. $\frac{\text { क }}{\mathbb{D}}$ As much as $50 \%$ could be lost at $4{ }^{\circ} \mathrm{C}$ and about $\stackrel{\odot}{\mathscr{P}}$ $90 \%$ at $20^{\circ} \mathrm{C}$ after the same period of time (Brozović $\stackrel{\unrhd}{\varrho}$ et al, 1971). 
No data on the stability of prothrombin and factor VII in freeze-dried plasma were found in the literature. Preliminary results (Bangham et al, 1970) indicated that prothrombin and factor VII activity also decreased on storage. We have therefore studied the stability of these factors in plasma preparations freeze dried under the optimal conditions used to prepare international standards.

\section{Materials and Methods}

FREEZE-DRIED HUMAN PLASMA

PREPARATIONS

Three preparations of freeze-dried human plasma, labelled 65/153,66/355, and 68/413, were used. Each was prepared from a pool of approximately 4 litres of plasma, collected into ACD from 20 donors at the Oxford Blood Transfusion Centre in 1965, 1966, and 1968 respectively. The individual blood donations were promptly centrifuged at $4^{\circ} \mathrm{C}$ to get rid of cells and then pooled.

The same day the pooled plasma was distributed at room temperature in equal amounts into hard glass ampoules. Vessels used for the plasma were previously rinsed out with sodium citrate; the ampoules were steamed in acid, extensively rinsed with distilled water and citrate, and sterilized by dry heat in a clean oven. Approximately 10-12 hours after the blood had been obtained from the donors the plasma in the ampoules was frozen at $-35^{\circ} \mathrm{C}$, placed in liquid nitrogen and then freeze-dried as one batch at $-35^{\circ} \mathrm{C}$. Thereafter the ampoules were fitted with plastic plugs designed to limit gaseous diffusion and subjected to secondary desiccation for 13 days. After the ampoules had been filled with pure dry nitrogen they were sealed by fusion of the glass.

The moisture content was estimated as loss of weight by the material after heating to $56^{\circ} \mathrm{C}$ over $\mathrm{P}_{2} \mathrm{O}_{5}$ in a vacuum for five hours. The oxygen content of the ampoules was estimated by mass spectrometry. The results obtained for the three plasmas are shown in Table I.

\begin{tabular}{lll}
\hline Plasma & Moisture Content (\%) & $\begin{array}{l}\text { Oxygen Content } \\
(\%)\end{array}$ \\
\hline $68 / 413$ & Negligible & 0.09 \\
$66 / 355$ & Less than 1 & $0 \cdot 15$ \\
$65 / 153$ & $2 \cdot 59$ & 4.39 \\
\hline
\end{tabular}

Table I Moisture and oxygen content of freeze-dried plasmas

After the ampoules had been tested for pinholes and cracks they were stored at $-20^{\circ} \mathrm{C}$ in the dark.
PROTHROMBIN DETERMINATIONS

The prothrombin content of the three plasmas was measured by a modification of the method of Ware and Seegers (1949). The reaction mixture consisted of 3 parts Michaelis buffer, 2 parts $25 \mathrm{mM} \mathrm{CaCl}_{2}$, and 3 parts phenolized freeze-dried human brain thromboplastin reconstituted in distilled water. The bovine factor $\mathrm{V}$ used was obtained from Diagnostic Reagents Ltd. Fibrindex thrombin (Ortho Pharmaceutical Ltd) was used to determine the standard curve for each assay.

\section{FACTOR VII DETERMINATIONS}

Factor VII was estimated by a one-stage method according to Denson (1967). An artificial factor VIIdeficient plasma (kindly provided by Dr Swart, Academisch Ziekenhuis, Leiden) and phenolized freeze-dried human brain thromboplastin were used throughout.

\section{ACCELERATED DEGRADATION TESTS}

These tests were performed as described by Jerne and Perry (1956). The samples of plasma were stored at $-20^{\circ} \mathrm{C}, 4^{\circ} \mathrm{C}, 20^{\circ} \mathrm{C}$, and $37^{\circ} \mathrm{C}$; plasma $68 / 413$ was investigated after 16 and 22 months, plasma $69 / 355$ after 39 months, and plasma $65 / 153$ after 49 and 56 months of storage at these temperatures.

\section{Results}

PROTHROMBIN CONTENT

The prothrombin content of the three freeze-dried plasmas, $68 / 413,66 / 355$, and $65 / 153$, stored at $-20^{\circ} \mathrm{C}$, was estimated to be equivalent to 255,210 , and $150 \mathrm{NIH}$ thrombin units per ml respectively. The prothrombin content of the plasmas decreased on storage as shown in Table II.

\begin{tabular}{|c|c|c|c|c|c|c|}
\hline \multirow[t]{2}{*}{ Plasma } & \multirow{2}{*}{$\begin{array}{l}\text { Time of } \\
\text { Storage } \\
\text { (mth) }\end{array}$} & \multicolumn{4}{|c|}{ Prothrombin Content at: } & \multirow{2}{*}{$\begin{array}{l}\text { Number of } \\
\text { Assays }\end{array}$} \\
\hline & & $-20^{\circ} \mathrm{C}$ & $4^{\circ} \mathrm{C}$ & $20^{\circ} \mathrm{C}$ & $37^{\circ} \mathrm{C}$ & \\
\hline $\begin{array}{l}68 / 413 \\
66 / 355 \\
65 / 153\end{array}$ & $\begin{array}{l}22 \\
39 \\
56\end{array}$ & $\begin{array}{l}255^{1} \\
210 \\
150\end{array}$ & $\frac{225}{138}$ & $\frac{157}{85}$ & $\begin{array}{l}50 \\
64 \\
-\end{array}$ & $\begin{array}{l}2 \\
4 \\
2\end{array}$ \\
\hline
\end{tabular}

Table II Prothrombin in freeze-dried plasmas

${ }^{1}$ Mean of two assays expressed as NIH units per ampoule

When degradation constants were calculated and the loss of potency estimated for plasmas $68 / 413$ and $65 / 153$, it became apparent that in 10 years at $-20^{\circ} \mathrm{C}$ up to $4 \%$ of the original activity may be lost. If stored for the same period at $4^{\circ} \mathrm{C}$ and $20^{\circ} \mathrm{C}$ the loss could be up to 30 and $80 \%$ respectively (Table III). 


\begin{tabular}{llll}
\hline Plasma & \multicolumn{3}{l}{$\begin{array}{l}\text { Estimated Potency Loss (as \% of the } \\
\text { Original Activity) in } 10 \text { Years at: }\end{array}$} \\
\cline { 2 - 4 } & $-20^{\circ} \mathrm{C}$ & $4^{\circ} \mathrm{C}$ & $20^{\circ} \mathrm{C}$ \\
\hline $68 / 413$ & 0.89 & 23.84 & 83.08 \\
$65 / 153$ & 3.90 & 29.35 & 69.98 \\
\hline
\end{tabular}

Table III Estimated potency loss in prothrombin after 10 years of storage

\section{FACTOR VII CONTENT}

The factor VII content of the three plasmas was studied at the same time and expressed as a percentage of activity in plasma $68 / 413$ stored at $-20^{\circ} \mathrm{C}$. It was estimated to be $93 \%$ and $72 \%$ for plasma $66 / 355$ and 65/153 respectively, as shown in Table IV.

\begin{tabular}{lllllll}
\hline Plasma & $\begin{array}{l}\text { Time of } \\
\text { Storage } \\
(\text { mth })\end{array}$ & \multicolumn{3}{l}{ Factor VII Content at: } & \multirow{2}{*}{$\begin{array}{l}\text { Number of } \\
\text { Assays }\end{array}$} \\
\cline { 3 - 6 } & $-20^{\circ} \mathrm{C}$ & $4^{\circ} \mathrm{C}$ & $20^{\circ} \mathrm{C}$ & $37^{\circ} \mathrm{C}$ & \\
\hline $68 / 413$ & 22 & $100^{1}$ & $95^{1}$ & 76 & 17 & 2 \\
$66 / 355$ & 39 & 93 & 101 & 63 & 5 & 3 \\
$65 / 153$ & 56 & 72 & 60 & 41 & - & 2 \\
\hline
\end{tabular}

Table IV Factor VII in freeze-dried plasmas

${ }^{1}$ Mean of two assays expressed as \% factor VII activity of plasma $68 / 413$ stored at $-20^{\circ} \mathrm{C}$.

Factor VII activity decreased on storage although to a lesser extent than prothrombin or factor $\mathrm{X}$ activity. The estimated loss after 10 years at $-20^{\circ} \mathrm{C}$ would be less than $2 \%$, and at $4{ }^{\circ} \mathrm{C}$ less than $18 \%$ of the original activity as shown in Table V. At room temperature, the plasmas were estimated to lose between 20 and $70 \%$ of factor VII activity in 10 years (Table V).

\begin{tabular}{llcc}
\hline Plasma & \multicolumn{3}{l}{$\begin{array}{l}\text { Estimated Potency Loss (as \% of the } \\
\text { Original Activity) in } 10 \text { Years at: }\end{array}$} \\
\cline { 2 - 4 } & $-20^{\circ} \mathrm{C}$ & $4^{\circ} \mathrm{C}$ & $20^{\circ} \mathrm{C}$ \\
\hline $68 / 413$ & 0.02 & 2.82 & 32.46 \\
$66 / 355$ & 0.75 & 17.53 & 70.79 \\
$65 / 153$ & 1.85 & 17.05 & 51.25 \\
\hline
\end{tabular}

Table V Estimated potency loss in factor VII after 10 years of storage

\section{Discussion and Conclusions}

The three preparations of plasma studied had been ampouled under the conditions developed to provide international standards for various biological substances. These studies show that even in plasma ampouled under these conditions neither prothrombin nor factor $\mathrm{X}$ (Brozović et al, 1971) were as stable at $-20^{\circ} \mathrm{C}$ as would normally be required for the preparations serving as long-term reference materials. Factor VII was found to be more stable than the other two factors.

The stability of all three factors in these plasma preparations suggests that plasma could be used as a $\overparen{\nabla}$ working standard for a few months or years providing it was stored below $4{ }^{\circ} \mathrm{C}$.

Plasma 65/153, stored for over four years, had a $\vec{\circ}$ higher moisture and oxygen content than plasmas $\overrightarrow{\vec{A}}$ $66 / 355$ and $68 / 413$. The content of prothrombin and $\omega$ factor VII in this plasma was low when compared 2 with that of the other two plasmas. However, the stability of the two factors was of the same order as in plasmas $66 / 355$ and $68 / 413$.

No buffer was added to the three preparations of $\emptyset$ plasma before freeze-drying. The addition of a 0 buffer, such as $\mathrm{N}-2$ hydroxyethyl-piperazine $\mathrm{N}-2-\stackrel{2}{-}$ ethanesulphonic acid (HEPES), may improve the $z$ stability of these factors. HEPES is known to stabilize the $p \mathrm{H}$ of the solution after reconstituting the freeze-dried material (Zucker, Cathey, and West, 1970), but little is known about its effect on the longterm stability of individual factors. Some preliminary results suggest that it improves the stability of factor VIII in freeze-dried plasma on short-term storage at $37^{\circ} \mathrm{C}$ (Denson, 1970).

The results of this study indicate that prothrombin and factor X may be insufficiently stable in freeze-dried plasma to allow the use of plasma as long-term $\mathbb{\Phi}$ reference material for the standardization of the one- $\underset{F}{\vec{F}}$ stage prothrombin time, and that for use as a working $\stackrel{3}{3}$ standard it should be stored at $-20^{\circ} \mathrm{C}$, and not at $4^{\circ} \mathrm{C}$. Further investigations into the effect of various buffers added to plasma before freeze-drying are needed.

\section{References}

Alderson, M. R. Poller, L, and Thomson, J. M. (1970). Validity of the British system for anticoagulant control using the national 을 reagent. J. clin. Path., 23, 281-285.

Bangham, D. R., Biggs, R., Brozovic, M., and Denson, K. W. E. I (1970). Draft report of a collaborative study of two thromboplastins (including the use of common abnormal plasma). Thrombos. Diathes. haemorrh. (Stuttg.) Suppl., 40, 341-351. O

Bangham, D. R., Brozović M., and Robertson, I. (1970). Stability of " some clotting factors in freeze-dried factor VIII reference $N$ plasma and concentrate. Abstracts of the VIth Congress of the $\mathrm{N}$ World Federation of Hemophilia. Baden, July 25-27, page 81. $\omega$

Biggs, R., and Bangham, D. R. (1971). Standardization of one stage $\sigma$ prothrombin time test for the control of anticoagulant therapy: availability and use of thromboplastin reference preparations. Brit. med. J., 2, 470-471.

Biggs, R., and Denson, K. W. E. (1967). Standardization of the one $\mathscr{S}$ stage prothrombin time for the control of anticoagulant therapy. Brit. med. J., 1, 84-88.

Brozović, M., Gurd, L. J., Robertson, I., and Bangham, D. R. (1971). Factor $\mathbf{X}$ in freeze-dried factor VIII reference plasmas. Brit. J. Haemat. 21, 201-208.

Denson, K. W. E. (1967). The Use of Antibodies in the study of Blood Coagulation, p. 206. Blackwell Scientific, Oxford and Edinburgh. 
Jerne, N. K., and Perry, W. L. M. (1956). The stability of biological standards. Bull. Wld Hlth Org., 14, 14, 167-182.

Loeliger, E. A., Menwisse-Braun, J. B., Buitendijk, F. J. J., Veltkamp, J. J., and Hemker, H. C. (1970). Laboratory control of oral anticoagulants. Definition of therapeutic range in terms of different thromboplastin preparation. Thrombos. Diathes. haemorrh. (Stuttg.), 23, 569-584.

Miale, J. B., and LaFond, D. (1967). 1963 Prothrombin time test survey. Amer. J. clin. Path., 47, 40-59.
Miale, J. B., and LaFond, D. (1969). Prothrombin timestandardization. Amer. J. clin. Path., 52, 154-160.

Poller, L., and Thomson, J. M. (1969). The interpretation of prothrombin results: a national survey. Brit. J. Haemat., 16, 31-37.

Ware, A. G., and Seegers, W. H. (1949). Two-stage procedure for the quantitative determination of prothrombin concentration. Amer. J. clin. Path., 19, 471-482.

Zucker, S., Cathey, M., and West, B. (1970). Preparation of quality control specimens for coagulation. Amer. J. clin. Path., 53, 924-927. 